Doi: 10.47650/pjphsr.v1i2.271

ISSN (Online): 2777-1296

OJS: http://journal.unpacti.ac.id/index.php/pjphsr

\title{
FACTORS RELATED TREATMENT COMPLIANCE WITH PULMONARY TUBERCULOSIS IN THE WORKING AREA OF BANGKALA HEALTH CENTER, MAKASSAR CITY
}

\section{Faktor faktor yang berhubungan dengan kepatuhan berobat penderita tuberkolosis paru di Wilayah Kerja Puskesmas Bangkala Kota Makassar}

\author{
Hasnawati S*, Hairuddin K, Risna Damayanti \\ Universitas Megarezky Makassar
}

*Alamat Korespondens: watihasnawati08@gmail.com

\begin{tabular}{l}
\hline Article Info \\
\hline Article History \\
Received: 26 Agustus 2021 \\
Revised : 01 September 2021 \\
Accepted : 04 September 2021
\end{tabular}

Keywords :

knowledge, attitude, behavior

\section{Kata kunci :}

pengetahuan, sikap, prilaku

\begin{abstract}
ABSTRAK
Tuberculosis (TB) is a directly infectious disease caused by the bacterium Mycobacterium tuberculosis. Pulmonary TB treatment compliance is crucial because if treatment is not carried out regularly and not by the specified time, it will lead to widespread immunity of TB germs to Anti-TB drugs. This study aims to determine the relationship between knowledge, attitudes, and behavior of pulmonary TB patients and treatment adherence in the Bangkala Health Center Work area, Makassar City. This research is an analytic study with a cross-sectional design. The population in this study is as many as 45 people with a sample size of 30 respondents based on inclusion criteria, using a sampling technique that is purposive sampling. Data was collected using a questionnaire, then processed and analyzed univariately, and bivariate analysis using the chi-square test $(\rho<=0.05)$. The results of the bivariate analysis showed that there was a significant relationship between knowledge $(\rho=0.016)$, attitude $(\rho=0.024)$, behavior $(\rho=0.026)$. This study concludes a significant relationship between knowledge, attitudes, and behavior of pulmonary TB patients with treatment adherence in the Bangkala Health Center Work Area, Makassar City.
\end{abstract}

Tuberkulosis (TB) Paru merupakan penyakit menular langsung yang di sebabkan oleh bakteri mycobacterium tuberculosis. Kepatuhan pengobatan TB Paru merupakan hal yang sangat penting, karena bila pengobatan tidak dilakukan secara teratur dan tidak sesuai dengan waktu yang telah ditentukan maka akan dapat menimbulkan kekebalan kuman TB terhadap Obat Anti TB secara meluas. Penelitian ini bertujuan untuk mengetahui hubungan pengetahuan, sikap dan perilaku penderita TB Paru terhadap kepatuhan berobat di wilayah Kerja Puskesmas Bangkala Kota Makassar. Penelitian ini merupakan penelitian analitik dengan rancangan cross sectional. Populasi dalam penelitian ini sebanyak 45 orang dengan besar sampel 30 responden berdasarkan kriteria inklusi, dengan menggunakan Teknik pengambilan sampel yaitu purpossive sampling. Pengumpulan data dilakukan dengan menggunakan kuesioner, kemudian diolah dan dianalisis secara univariat, dan analisis bivariat menggunakan uji chi square $(\rho<\alpha=0,05)$. Hasil analisis bivariat didapatkan ada hubungan yang bermakna antara pengetahuan $(\rho=0,016)$, sikap $(\rho=0,024)$, perilaku $(\rho=0,026)$. Kesimpulan dalam penelitian ini yaitu ada hubungan yang siginifikan antara pengetahuan, sikap dan perilaku penderita TB Paru terhadap kepatuhan berobat di Wilayah Kerja Puskesmas Bangkala Kota Makassar. 


\section{PENDAHULUAN}

Tuberkulosis (TB) adalah penyakit menular yang biasanya menyerang paru-paru dan disebabkan oleh bakteri Mycobacterium tuberculosis, meskipun dapat mengenai organ apa pun di dalam tubuh. Infeksi TB berkembang ketika bakteri masuk melalui droplet di udara. TB bisa berakibat fatal, tetapi dalam banyak kasus, TB dapat dicegah dan diobati. TB adalah penyebab utama kematian di seluruh dunia. Setelah perbaikan dalam terapi dan perkembangan antibiotik, prevalensi TB turun secara dramatis di negara-negara industri.

Wold Health Organization (WHO) melaporkan bahwa TB adalah salah satu dari 10 penyebab utama kematian secara global dan "penyebab utama kematian dari satu agen infeksius." WHO memperkirakan bahwa pada tahun 2018, hampir 10 juta orang di seluruh dunia menderita TB dan 1,5 juta orang meninggal karena penyakit ini, termasuk 251.000 orang yang juga menderita HIV. Kementerian Kesehatan Republik Indonesia melaporkan kasus TB di Indonesia hingga saat ini 842.000 kasus dan memiliki Case Fatality Rate/CFR atau meninggal karena penyakit adalah 16\% (WHO, 2017).

Pravelensi di Indonesia TB paru tahun 2019 mengenai pengetahuan, sikap dan prilaku dari lingkungan sebesar $13 \%$, keluaga yang pernah mendengar tentang TB sebanyak 8, menunjukkan bahwa keluarga yang merawat anggota keluarganya yang menderita TB sebesar 96\%, penderita yang menyembunyikan keberadaannya $5 \%$, namun demikian hanya $26 \%$ masyarakat yang dapat menyebutkan dua tanda dan gejala TB, pemahaman tentang TB oleh keluarga sebesar $51 \%$, dan hanya $19 \%$ yang mengetahui tersedianya obat TB yang bisadidapatkansecara gratis. hal ini menyebabkan sulitnya penanganan penyakit TB (Kemenkes, 2019)

Tahun 2019 angka penemuan kasus baru untuk provinsi Sulawesi selatan yaitu hanya $18,93 \%$ padahal target yang harus dicapai lebih dari 40\%. Target angka kesembuhan untuk Sulawesi selatan lebih dari $85 \%$ untuk tahun 2013 ,sedangkanangka kesembuhan yang tercapai hanya $81,46 \%$. Berarti dapat disimpulkan bahwa target angka penemuan kasus baru dan angka kesembuhan penyakit TB belum tercapai secara maksimal (Dinkes, 2021)

Berdasarkan Data yang ada dipuskesmas Bangkala, jumlah pasien pada tahun 2018 bulan januari sampai bulan oktober adalah 45 pasien. hasil wawancara pada masyarakat diwilayah kerja Puskesmas Bangkala masih ada sebagian masyarakat yang beranggapan bahwa penyakit TB Paru tidak berbahaya dan merupakan penyakit biasa karena kesibukannya mereka berlama-lama atau membiarkan saja batuk yang dirasakan sehingga masyarakat kurang peduli dengan gejala yang dialaminya dengan membiarkan batuk yang lebih dari 3 minggu dan mereka hanya meminum obatyang dibeli penjual terdekat, dan keptuhannya minum obat terkadang lupa minum obat di karenakan kesibukannya dalam mencari nafkah untuk keluarganya sehingga meminum obat tidak teratur dan sebaliknya jika penyakit yang dideritanya masih belum sembuh barulah mereka pergi kepuskesmas untuk mendapatkan pengobatan (Erawatyningsih, 2019)

Penelitian ini bertujuan untuk Mengetahui faktor yang berhubungan dengan kepatuhan berobat penderita penyakit TB Paru di Wilayah Kerja Puskesmas Bangkala Kota Makassar.

\section{BAHAN DAN METODE}

Jenis penelitian yang digunakan adalah penelitian observasional analitik dengan rancangan cross sectional study. Lokasi penelitian dilakukan di Wilayah kerja Puskesmas Bangkala Kota Makassar. Pelaksanaan penelitian dilakukan bulan Maret sampai April 2021. Populasi penelitian seluruh pasien penderita TB paru di Puskesmas Bangkala Kota Makassar tahun 2021. Sampel pada penelitian ini adalah 30pasien penderita TB paru di Puskesmas Bangkala 
Kota Makassar tahun 2021diambil secara accidental sampling. Pengumpulan data menggunakan kuesioner terhadap 30 responden meliputi identitas diri, tingkat pengetahuan, sikap dan perilaku. Analisa data untuk melihat hubungan variable independent terhadap variable dependen dengan menggunakan Chi-Square dengan tingkat kemaknaan $p<\alpha(0,05)$ yang diolah dengan menggunakan SPSS versi 21.0.

\section{HASIL}

\section{Karakteristik Responden}

Karakteristik responden disajikan dalam tabel 1 berdasarkan umur, jenis kelamin, pekerjaan, tingkat pendidikan.

\section{Tabel 1. Karakteristik Responden}

\begin{tabular}{lcc}
\hline Karakteristik Responden & $\mathbf{n}$ & $\mathbf{\%}$ \\
\hline Umur & & \\
\hline $15-25$ & 15 & 50 \\
$26-45$ & 10 & 33.3 \\
\hline $46-75$ & 5 & 16.7 \\
Jenis Kelamin & & \\
$\quad$ Laki-laki & 23 & 76.7 \\
\hline Perempuan & 7 & 23.3 \\
Pekerjaan & & \\
\hline Tidak bekerja & 3 & 10 \\
\hline Wiraswasta & 17 & 57.7 \\
\hline Pegawai swasta & 1 & 3.3 \\
\hline Buruh harian & 9 & 30 \\
\hline Pendidikan & & \\
\hline SD & 7 & 23.3 \\
\hline SMP & 9 & 30 \\
\hline SMA & 10 & 33.3 \\
\hline S1 & 1 & 3.3 \\
\hline Tidak sekolah & 3 & 10 \\
\hline Total & $\mathbf{3 0}$ & 100 \\
\hline
\end{tabular}

Sumber : Data Primer, 2021

Tabel 1 menunjukkan Kelompok umur yang paling banyak yaitu pada kelompok umur 1525sebanyak 15 orang (50\%) dan paling sedikit adalah responden pada kelompok umur 4675 tahun sebanyak 5 orang $(16,7 \%)$. Responden yang berjenis kelamin laki laki23 $(76,7 \%)$ dan responden yang berjenis kelamin perempuan sebanyak 7(23,3\%). Berdasarkan Pekerjaan menunjukkan bahwa persentase terbesar adalah responden dengan pekerjaan wiraswasta sebanyak 17 orang $(56.7 \%)$ dan persentase terendah pengawai swasta sebanyak 1 orang $(3,3 \%)$. Sedangkan pada tingkat pendidikan menunjukkan bahwa paling banyak memiliki tingkat pendidikan SMA yaitu sebanyak 10 orang(33,3\%) dan responden yang paling sedikit adalah responden dengan pendidikan $\mathrm{S} 1$ sebanyak 1 orang $(3,3 \%)$.

\section{Distribusi Responden}

Distribusi responden disajikan pada tabel 2 berdasarkan pengetahuan, sikap, prilaku, kepatuhan berobat menunjukkan bahwa sebagian besar responden memiliki pengetahuan yang baik tentang tuberkulosis paru. $\mathrm{Hal}$ ini terlihat dari 30 $(100 \%)$ responden terdapat $18(60 \%)$ responden yang memiliki pengetahuan baik, sedangkan responden yang memiliki pengetahuan tidak baik sebanyak 6 (20\%). Hasil analisis statistik dengan menggunakan uji "Chi-Square" didapatkan nilai $p=$ 0.016 yang berarti lebih kecil dari nilai $\alpha=0,05$. Maka Ho ditolak dan Ha diterima. Maka dapat disimpulkan dalam penelitian ini bahwa ada hubungan antara pengetahuan penderita TB Paru dengan kepatuhan berobat. Pada sikap responden diperoleh yang terbanyak pada sikap negatif sebanyak 13 orang $(43,3 \%)$ hasil analisis statistik dengan menggunakan uji "Chi-Square" didapatkan nilai $p=0.021$ yang berarti lebih kecil dari nilai $\alpha=$ 0,05 . Maka Ho ditolak dan Ha diterima. Maka dapat disimpulkan dalam penelitian ini bahwa ada hubungan antara sikap penderita TB Paru dengan kepatuhan berobat. Sedangkan pada perilaku didapatkan responden yang paling banyak pada perilaku baik 17 (56,7\%) dibandingkan dengan responden dengan prilaku kurang baik $7(23,3 \%)$. 
Hasil analisis statistik dengan menggunakan uji

"Chi-Square" didapatkan nilai $\mathrm{p}=0.018$ yang berarti lebih kecil dari nilai $\alpha=0,05$. Maka disimpulkan dalam penelitian ini bahwa ada hubungan antara perilaku penderita TB Paru dengan kepatuhan berobat.

Tabel 2. Tabulasi silang faktor yang berhubungan

\begin{tabular}{|c|c|c|c|c|c|}
\hline \multicolumn{2}{|c|}{ Faktor berhubungan } & \multicolumn{2}{|c|}{ Kepatuhan Berobat } & \multirow{2}{*}{ Total } & \multirow{2}{*}{ p-value } \\
\hline & & Patuh & Tidak Patuh & & \\
\hline \multirow[t]{2}{*}{ Pengetahuan } & Baik & $18(60)$ & $1(3,3)$ & $19(63,3)$ & \multirow{3}{*}{0,016} \\
\hline & Tidak Baik & $6(20)$ & $5(16,7)$ & $11(36,7)$ & \\
\hline \multirow[t]{2}{*}{ Sikap } & Positif & $11(36,7)$ & $6(20)$ & $17(56,7)$ & \\
\hline & Negatif & $13(43,3)$ & $0(0)$ & $13(43,3)$ & \multirow[t]{2}{*}{0,021} \\
\hline \multirow[t]{2}{*}{ Perilaku } & Baik & $17(56,7)$ & $1(3,3)$ & $18(60)$ & \\
\hline & Kurang Baik & $7(23,3)$ & $5(16,7)$ & $12(40)$ & 0,026 \\
\hline
\end{tabular}

Sumber: Data Primer, 2021

\section{PEMBAHASAN}

\section{Hubungan pengetahuan dengan kepatuhan berobat}

Dari hasil penelitian ini, jumlah penderita yang memiliki pengetahuan baik lebih banyak yang patuh dalam berobat daripada penderita yang memiliki pengetahuan kurang baik namun patuh dalam berobat. Dikarekanan penderita yang mulai bosan dengan pengobatan yang berjangka panjang dan kurangnya pengetahuan efek dari pengobatan yang tidak patuh yang akan sulit untuk diobati. Kepatuhan penderita dipengaruhi oleh kemauan dan motivasi diri untuk sembuh didukung dari dukungan keluarga, masyarakat dan pengawas minum obat dalam keluarga.

Hal ini diakibatkan oleh masih ada penderita yang tidak datang selama fase intensif karena tidak adekuatnya motivasi terhadap kepatuhan berobat dan kebanyakan penderita merasa baik pada akhir fase awal dan merasa tidak perlu kembali untuk pengobatan selanjutnya, ini semua karena persepsi yang salah dan kurangnya motivasi dari keluarga sebagai pendorong untuk tetap patuh dan teratur berobat baik itu penyakitnya sendiri maupun resistensi obat yang akan ditimbulkan (Budiharto, 2018).

$\mathrm{Hal}$ ini sejalan dengan penelitian yang dilakukan oleh Pasek dkk, (2018) tentang hubungan tingkat pengetahuan penderita tuberkulosis dengan kepatuhan pengobatan di wilayah kerja puskesmas buleleng yang menyatakan ada hubungan yang signifikan antara pengetahuan dengan kepatuhan pengobatan TB.

Berdasarkan hasil observasi dilapangan, peneliti melihat ketidakpatuhan berobat secara teratur bagi penderita TB paru tetap menjadi hambatan untuk mencapai angka kesembuhan yang tinggi. Hal ini dikarenakan penyuluhan kesehatan diberikan tidak menyeluruh dan kurangnya informasi yang didapatkan mengenai penyakit TB paru secara mandiri. Penyuluhan perorang akan lebih efektif dan lebih besar kemungkinan tingkat keberhasilan pengobatan dibanding dengan cara penyuluhan melalui media, karena kurangnya informasi yang diperoleh tentang penyakit TB paru, cara pengobatan, bahaya akibat tidak teratur minum obat dan pencegahannya.

\section{Hubungan Sikap dengan Kepatuhan Berobat}

Dari hasil penelitian yang telah dilakukan, jumlah penderita yang memiliki sikap negatif lebih banyak yang tidak patuh dalam berobat daripada penderita yang memiliki sikap positif. Hal ini menunjukkan bahwa semakin positif sikap seseorang, semakin besar kecenderungan untuk menjalani pengobatan. Sebaliknya semakin 
negatif sikap seseorang, semakin besar kecenderungan untuk tidak menjalani pengobatan.

Sikap/anggapan adalah suasana batin atau hasil dari proses sosialisasi yaitu reaksi seseorang terhadap rangsangan yang diterimanya. Contohnya, sikap keluarga yang menolak ke dokter meskipun penderita mengalami batuk dan demam, sebab menurutnya batuk dan demam cukup diobati dengan obat penurun panas dan minum obat tradisional. Menurut pengalamannya atau berdasarkan pengalaman orang, cara dan bahan tersebut "mampu menyembuhkan" (Budiharto, 2018).

Hal ini sejalan dengan hasil penelitian yang dilakukan oleh Nugroho Priyo Handoko (2017) tentang hubungan sikap dengan penyakit tb di bbkpm Surakartabahwa ada hubungan sikap dan kepatuhan pengobatanpenderita terhadap penyakit $\mathrm{TB}$, diperoleh nilai $p=0,021$ karena $p=0,05$. Hal tersebut berarti bahwa sikap penderita tentang pengobatan penyakit TBC yang baik akan mendorong masyarakat untuk melakukan mengembangkan sikap pencegahan dan pengobatan yang baik dalam menangani penyakit TBC. Penderita yang memiliki sikap negatif lebih cenderung tidak patuh dalam melakukan pengobatan dibandingkan dengan penderita yang memiliki sikap positif.

Berdasarkan hal tersebut maka peneliti berasumsi bahwa sikap yang positif akan memberikan pengaruh kepada penderita untuk melakukan tindakan yang mengarah ke hal positif dikarenakan adanya dukungan keluarga sehingga dapat meningkatkan kepatuhan dalam berobat bagi penderita TB paru.

\section{Hubungan Perilaku dengan Kepatuhan Berobat}

Dari hasil penelitian ini, jumlah penderita yang memiliki perilaku kurang baik lebih banyak yang tidak patuh dalam berobat daripada penderita yang memiliki perilaku baik. Dikarenakan penderita itu sendiri yang mampu atau tidak mampu memanfaatkan fasilitas kesehatan yang telah disediakan dan kebanyakan perilaku penderita yang kurang baik dalam memotivasi dirinya untuk melakukan pengobatan karena motivasi yang tidak adekuat.

Fibriana, L. P (2019) menjelaskan bahwa hal penting yang mempengaruhi kesehatan adalah perilaku pencegahan penyakit dan perilaku pemulihan kesehatan. Perilaku pencegahan penyakit pada keluarga dipengaruhi oleh pengetahuan dan sikap. Penderita yang memiliki perilaku baik lebih cenderung tidak patuh dalam melakukan pengobatan dibandingkan dengan penderita yang memiliki perilaku kurang baik. Karena perilaku yang baik akan memberikan pengaruh kepada penderita untuk melakukan tindakan yang mengarah ke hal yang positif.

Hal ini sejalan dengan penelitian yang dilakukan oleh (Nugroho, 2021) tentang analisis hubungan peran keluarga dengan perilaku pencegahan TBC memiliki hubungan yang signifikan antara peran keluarga dengan perilaku pencegahan klien TBC. Hasil uji statistik hubungannya masih tetap signifikan $(p=0,001)$ berarti Ho ditolak dan Ha di terima.

Berdasarkan hasil yang diperoleh dari lapangan, maka peneliti melihat bahwa perilaku yang baik tidak selamanya patuh dalam berobat karena perilaku dapat dipengaruhi oleh pengetahuan dan sikap dari penderita itu sendiri dalam melakukan tindakan pengobatan

\section{KESIMPULAN DAN SARAN}

Penelitian menyimpulkan bahwa ada hubungan yang kuat antara pengetahuan, sikap dan prilaku dengan kepatuhan berobat pada TB Paru di Wilayah kerja Puskesmas Bangkala Kota Makassar

Bagi pihak Puskesmas bahwa perlunya petugas kesehatan aktif dalam upaya peningkatan keteraturan pengobatan pasien TB Paru dengan melakukan kerjasama dengan keluarga penderita sebagai bentuk dukungan dan pengawasan 
terhadap pengobatan penderita serta melakukan penyuluhan kepada masyarakat agar memahami penyakit TB Paru.

\section{DAFTAR PUSTAKA}

Aditama, T. Y., 2017. Tuberkulosis rokok \& perempuan. Jakarta: Fakultas Kedokteran Universitas Indonesia.

Budiharto, 2018. Pengantar IImu Prilaku Kesehatan dan Pendidikan Kesehatan. Jakarta: EGC.

Dinkes, 2021. Profil Kesehatan Kota Makassar. Januari.

Erawatyningsih, 2019. Faktor faktor yang berhubungan dengan ketidakpatuhan berobat pada penderita Tuberkulosis Paru.

Fibriana, L. P., 2019. Hubungan antara sikap dengan prilaku keluarga tentang pencegahan penyakit menular Tuberkulosis.

Firdaus, 2018. Faktor faktor penderita Tuberkulosis Paru putus berobat.
Kemenkes, 2019. Buletin jendela epidemiologi tuberkulosis di Indonesia. Analisis epidemiologi deskriptif tuberkulosis di Indonesia.

Konoli, F., 2018. Pengantar Epidemiologi Penyakit Menular untuk Mahasiswa Kesehatan Masyarakat.

Nugroho, H., 2021. Hubungan tingkat penghasilan, pendidikan, pengetahuan dan sikap pencehatan serta pengobatan dengan penyakit TBC di BPKPM Surakarta.

Pasek, 2018. Hubungan persepsi dan tingkat pengetahuan penderita Tuberkulosis dengan kepatuhan berobat di Puskesmas Buleleng. ejournal.litbang.depkes.go.id.

Saryaono, 2011. Metodologi Penelitian Kesehatan. Jogjakarta: Mitra Cendikia.

Notoatmojo S., 2010. Metodologi Penelitian Kesehatan. Jakarta: Rineka Cipta.

(WHO), W.H.O, 2017. Maternal Mortality. Wold Health Organization 